\title{
10 An analysis of transit safety among college students in Lagos, Nigeria
}

\author{
Smart E. Otu and Augustine Agugua
}

\subsection{Introduction}

Fear and actual crime on Public Transport System (hereafter known as PTS) can have a negative effect on how the service is used, and thus on the sustainability of the city. Safety therefore remains one of the most important qualities of good transport whether public or private. It is often noted that if people do not feel safe on a public and private transport system, they are less likely to use it, let alone linger in it (Iveson, 2018). Safety implies less crime or no crime at all. To all intents and purposes, crime implies risk to the physical safety of both passengers and staff, as well as financial losses, but it is more about risk to the physical and emotional well-being of commuters especially those using public transport. Worldwide, women are often more sexually victimized while in transit then men (Loukaitou-Sideris, Liggett \& Iseki, 2001; Smith, 2008; Ceccato and Paz, 2017).

In countries such as the UK, Japan, and countries of the European Union, public transport providers are committed to providing security to their citizenry, and their policy is, in general, gender-sensitive (see for example Gekoski et al., 2015). For instance, providers continue to send messages by advising commuters to regulate their behavior to stay safe. However, in countries of the Global South, such as Nigeria, such commitment is a far cry from being found. Instead, women are adopting their own coping strategies, such as changing their dressing code and taking precautionary measures to avoid sexual crime victimization while using public transportation. The lack of attention and sensitivity to the role of gender in public transport safety in Nigeria, and the fact that no factors of race, age, disability, socio-economic status, sexuality and gender intersect to influence public and private investors' approach to PTS with regard to safety in Nigeria, is the singular most important motivation for this study.

The main aim of this chapter is to report transit safety conditions in bus/ tricycle and motorcycle stops as experienced by college students in Lagos, Nigeria. That is, how do undergraduates of the University of Lagos, especially female ones, rate the level of safety of public transport services? The objectives are twofold: (1) to document the various and degrees of crimes, delinquency and antisocial behaviors most experienced by Nigerian female undergraduates using PTS; (2) to build on the emerging data and suggest new approaches to 
the design and delivery of urban public transport services to support the complex needs of all urban residents in Nigeria. The data for this analysis were collected as part of a global research project conducted in multiple cities from six continents: Africa, Asia, Australia/Oceania, Europe, North America, and South America. For more details, see Ceccato and Loukaitou-Sideris (2020).

\section{Statement of the problem}

Police records show that crime and disorder on PTS are not uncommon, and they include mainly stealing, robbery, obtaining by pretense (OBT), unlawful possession, assaults, insults and outright molestation and harassment by both touts and drivers (Otu, 2017). In a sarcastic, but well-founded treatise and warning to visitors to Africa, written two decades ago and entitled 'So You're Planning a Trip to Africa', Scott Bidstrup (1999, 3 and cited in Otu, 2003, 56) illuminates the seriousness of crime, especially armed robbery on PTS in Nigeria. Bidstrup warned the would-be-visitors to Nigeria to be wary of armed bandits when travelling on Nigerian roads. As he put it inter alia:

... Never travel at night. Armed robbery is always every time in Nigeria, but is much worse at night.... Daytime travel isn't safe, but it is much safer than night times travel. Never carry all your money with you. If you get robbed, and they find your money (and yes, they will, no matter how clever you think you are), you'll end up penniless in a country that doesn't know the meaning of the words "credit cards", "wire transfers", "ATM", or "bank credit"...

$($ Otu, 2003, 56)

Of all the crimes and safety issues confronting public transport users, robbery, assault and pickpocketing, sexual harassment or the fear of it, in their various forms, remain the most common ones. Sexual harassment remains the crime most faced by women who use PTS. This includes stalking, unwanted touching, obscene gestures, voyeurism, unwanted sexual comments or jokes, unwanted offensive and invasive interpersonal communication through electronic devices or social media, and sex-related insults. Kalms and Korsmeyer (2017a, 2017b) are of the view that the fear of sexual harassment in urban areas predisposes girls and women to regularly modify their behavior to reduce their risk of harassment. Extended, this explains the reason why more women and girls are less likely to undertake travel using PTS compared with their male counterparts.

In terms of time, many cannot afford to travel late. And whenever they do, women and girls make the most meticulous decisions about their clothing, finding a male to go out with them and/or trying to limit their movements to particular areas of the city (see also Kalms \& Korsmeyer, 2017a, 2017b). In Nigeria, there are instances when girls and women have refused to board public transport because of the dominance of males/boys in the bus, taxi or coach (Otu, 2017). The socio-psychological implication is that women are internalizing and 
taking very seriously, the traditional message that safety from sexual harassment is solely their responsibility.

\section{Theoretical framework}

The broad conceptual model of Environmental criminology theory (Bottoms \& Wiles, 1997; Clarke \& Eck, 2003) is relevant to this study because it examines how the convergence of a number of factors in a public space results in the occurrence of crime. It draws insights from the principles and assumptions of the three most influential and traditional theories of environmental criminology, namely rational, routine activities and crime pattern theories (see Brantingham \& Brantingham, 1993; Clarke \& Eck, 2003; Cohen \& Felson, 1979; Cornish \& Clarke, 1986).

However, Crime Pattern Theory (a strand of environment criminological theory) is reviewed and adopted here because it synthesizes all the elements of other environmental criminology theories, with the central point of departure being that crime is simply an event that occurs when an individual with some criminal readiness level meets a suitable target in a situation sufficient to activate that readiness potential. Crime Pattern Theory, which focuses on the public transport arena, talks about nodes, paths, edges, crime generators and crime attractors as key in explaining the complex interaction of settings involving the structures of PTS. Brantingham and Brantingham (1993) examined static crime events on PTS and found that public transport stations may be either crime generators, crime attractors or just fear generators.

Public transport operations in metropolitan Lagos involve all key elements of Crime Pattern Theory of both the offenders and the victims: suitable targets (for example, staff, passengers, presence of large liquidity and valuable property), motivated offenders (for example, unemployed youths, area boys, loiters, touts [agberos]), and the absence of capable guardians (for example, police officers, security staff, CCTV cameras) (see Otu, 2017). Although, there is a remarkable improvement on PTS in Lagos in the past couple of years, it is still apparently unsystematic, poorly organized and managed especially in relation to international best practices. The physical characteristics of bus stops/stations lack measures such as fencing, lighting, open design and security hardware that would prevent crime and disorder; they also lack other state and local council support services (see also Harris, 1971).

\subsection{Previous studies on transit safety around the world}

Of all the factors that influence the choice of a mode of transportation for one's routine activities, safety stands out as the most important. Chen and Gursoy (2001) reported that satisfaction and reliability are affected by two behavioral attitudes, which are perceptions of safety and comfort during a journey. Borhan, Ibrahim, Syamsunur, and Rahmat (2019) revealed that many respondents, 
especially the women they interviewed, were concerned about reckless driving and violation of traffic rules, which not only give an impression of - but also reflected the fact that - the safety of passengers was being compromised.

Women consider security as the main criterion in choosing public transportation (Nurdden, Rahmat, \& Ismail, 2007). A good customer service provided by an employee or a bus driver can evoke a good perception about public transportation in general and buses in particular. Further, Borhan et al. (2019) explained that a number of respondents they interviewed complained about the attitude of the bus drivers who failed to show regard for users, and did not treat passengers with respect. Both Okpara (1988) and Otu (2017) noted that the activities of the touts-locally known as agberos - were a source of worry to public transport users, especially females who are subjected to undignified treatments in the name of hustling for customers. Overall satisfaction of bus users is therefore directly affected by the negative experiences they have when using public transport, such as delays, or bad treatment from employees of the bus providers (Friman, 2004; Friman, Edvardsson, \& Gärling, 1998). What this suggests is that bus operators must seek to enhance customer service in an effort to further enhance customers' satisfaction.

PTS is fraught with additional challenges, thus restraining the preference for it. These challenges include unavailability or inaccessibility to some residents, its erratic schedules and long travel times due to frequent stops and pick-ups (see also Borhan et al., 2019). All these make using private car a more comfortable and attractive option.

Although men are more often victims of crime on public transport than women (Morgan \& Smith, 2006, cited in Smith, 2008; Smith \& Cornish, 2006), for women, fear of crime is obviously higher (Guilloux, 2012; Smith, 2008). This is exemplified by the elaborate protective measures that women impose on themselves. A recent study showed that all women are more likely to adopt specific transport practices that range from vigilance to avoidance for fear or real victimization (Guilloux, 2015).

Sexual harassment, mugging and assault remain a fear among women more than men (see TTC et al., 1989 cited in Smith, 2008; Smith, 2008). It is also revealed that certain types of crime are peculiar to some countries more than to others. In 2016, Colombia, Mexico and Venezuela, for example, were particularly at risk of kidnappings (Control Risks, 2016). This is also reflected on public transport, particularly taxis, where what is known as "express kidnapping" or a "millionaire tour" [paseo millonario] can happen. In these crimes, the passenger is forced by accomplices who get into the taxi to withdraw cash from cash machines (Cawley, 2014).

On crime and deviant behavior on the PTS, the social milieu has been identified as a strong risk factor (see Loukaitou-Sideris et al., 2001). According to the International Centre for Crime-Prevention (n.d.), several studies have shown that crime is correlated with districts surrounding transit stops: crime at transit stops is generally higher when the crime rate in the areas in which the stops are situated is high (see also Loukaitou-Sideris et al., 2001). This is valid for both 
transit stops and the vehicles themselves, since crime on public transport vehicles is higher on routes that go through zones with high crime rates (Newton, 2004). So, environments characterized by high densities of passengers (overcrowding), e.g., in buses, carriages or stations, are commonly a fertile territory for sexual harassment and other types of sexual abuse and harassment (Ceccato \& Paz, 2017). This argument falls in line with the general sociology-criminology causes of crime. Although overcrowding is not considered here to be a cause of sexual crime against women in transit, it is definitely a facilitator.

UITP (2014) on environment-crime-PTS found that, in France for example, violence against staff is more common in disadvantaged districts; and there is more fraud on buses in districts with high levels of violence (Le Parisien, 2011). In highly clustered parks in Lagos and Port Harcourt, there are reports of pickpocketing, robbery and various kinds of deviant behaviors aimed towards women. Some studies show that offences are more common on public transport when the surrounding districts have lower socio-economic levels (see, for example, Loukaitou-Sideris et al., 2001), particularly a high unemployment rate (Cozens, Neale, Whitaker, \& Hillier, 2003). For example, in Bogotá, the probability of a homicide near a bus stop (TransMilenio) is five times greater in a poor district than in other districts (Schäfer, 2015).

This literature review has shown the gap which exists in the study of public safety and crime on PTS in a developing country such as Nigeria. The lack of robust research on the diverse crime and safety issues on public transport in Lagos metropolitan city opens up a vista of areas to explore. As such, the present research provides the much-needed database for comparative studies at the international level.

\subsection{The case study}

Lagos is a cosmopolitan city in all senses. It is nicknamed the 'Centre of Excellence' because all political, economic, social and cultural activities which reflect the diverse nature of Nigeria are found in the city. It, equally, is a home for many residents who come from different ethnicities, socio-economic backgrounds, nationalities, languages/dialects and religious beliefs. Lagos is arguably the most or second-most populated city in Nigeria, with a vibrant economy and well-developed public and private transport system (Otu, 2017). According to National Bureau of Statistics, Demographic Statistics Bulletin (2017), Lagos's population was projected to hit 12,550,598 in 2016 (note that the last time population census was conducted in Nigeria was 2006, so population growth since then has been based on projection). Road traffic congestion management and parking infrastructural planning in metropolitan Lagos is a very big challenge to Lagos state government.

Lagos, unarguably, is a city that has one of the most extensive road networks (with beautifully designed flyovers) in the whole sub-Saharan Africa region. While this road network is supported by suburban train and state and local powered ferry services, they are underdeveloped. A modern rail system, spanning part of 
the Federal Government Revitalizing Rail Project, is currently under construction. The state government is struggling to make PTS safe and comfortable through numerous reforms and policies. All this notwithstanding, compared with other cities in the western world, reported cases of crime and disorder on public transport in Lagos are a source of concern to all critical stakeholders.

Public transport plays a critical role in ensuring the mobility of a large proportion of households in Lagos. Salau (2015) explained that with a population of over 20 million people, about 80 percent of the total daily passengers' trips in Lagos metropolis were made by public transport. Estimates of transport demand in metropolitan Lagos in 1990 ranged from seven million to 10 million passenger trips daily, of which over 95 percent were undertaken by road, primarily by private cars, public buses and taxis, and commercial motorcycles (Opeifa, 2012). In specific terms, between 80 and 85 percent of passenger trips are made by public transport (Opeifa, 2012). Figure 10.1 illustrates the outdoor environment of public transportation in Nigeria.

As it affects Metropolitan Lagos, public transport stations are crowded by people who do not know one another, thus creating the enabling environment for crime and disorder to occur with ease. As an illustration, at certain periods in people's routine activities, the crowds and the characteristics they exhibit (e.g., commuters using public transport during morning and evening rush hours or festive periods) would yield suitable conditions for certain kinds of crime (e.g., attracting offenders who believe they have greater opportunity either to pickpocket, steal valuables or displaying some kinds of unwanted sexual behavior). By this, both the stations and periods act as crime attractors. Brantingham and Brantingham $(1993,1995)$ further explained that fear of crime on PTS can be generated in a number of ways: (i) if the surroundings appear unclean, (ii) if stations appear uncared for, and (iii) if stations are not properly lit or are poorly supervised.

(a)

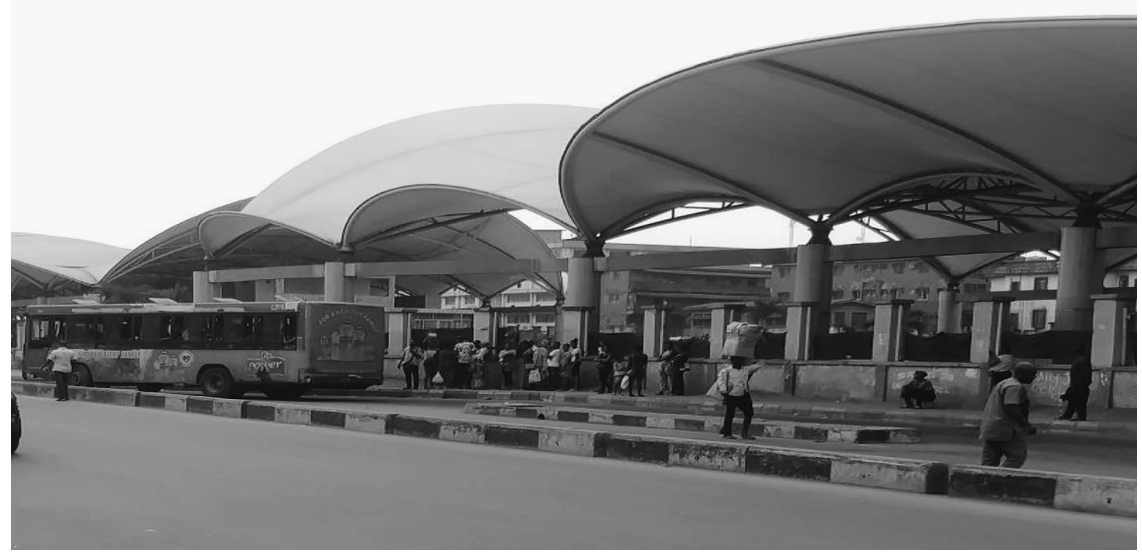


(b)

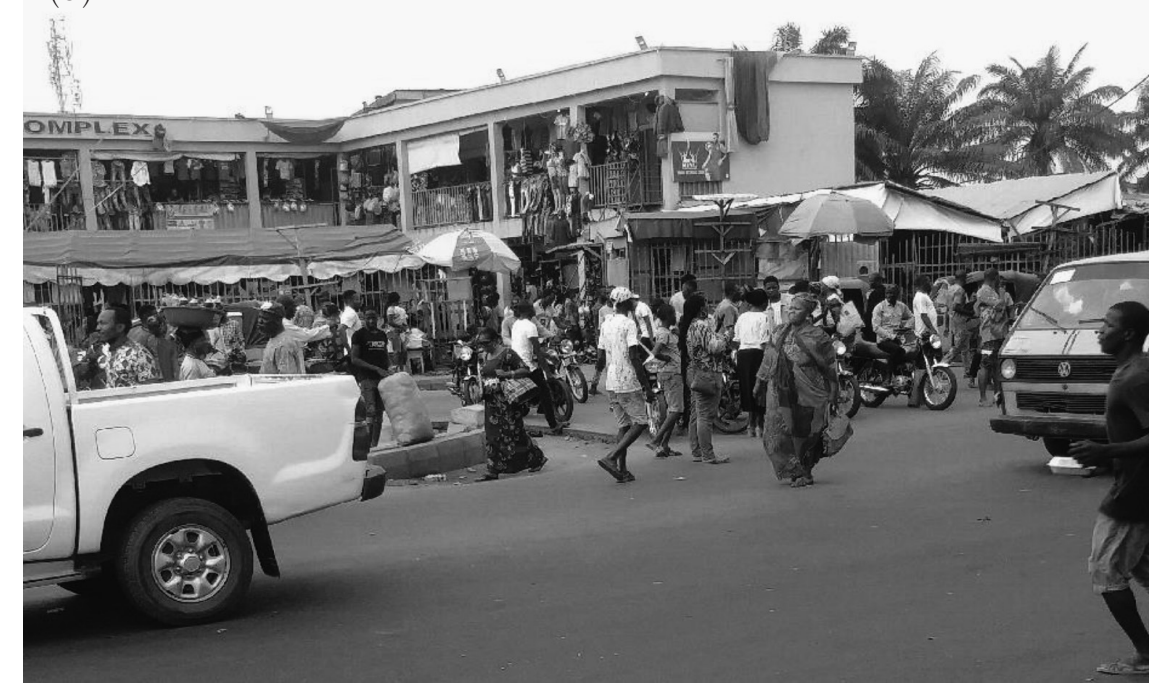

Figure 10.1 (a) A typical modern LAMA and LAMTA bus station. (b) Molue bus station in Lagos, Nigeria.

Source: Picture taken by author during the course of the research.

There are many crimes, such as armed robbery, sexual misconducts, theft, pickpocket, assault, violence, bag and purse snatching, which characterize PTS in Lagos. These crimes are more of a reflection of the disorganized social context (milieu) of public transport spaces in Lagos (unclean environment, poorly lit and supervised stations/parks), and of course, individual predisposing factors. There are certain individual behaviors which are associated with both the operation and use of PTS in Lagos, and which further provide additional crime generators and attractors for motivated offenders. These behaviors include users of public transport carrying large amounts of cash and/or valuables, dressing in certain ways, not been security conscious. The many motivated offenders include the agberos (motor park loaders), young and unemployed men and women who mill around and hawk items in and around the park stations. In addition, PTS in Lagos lacks effective guardians (security systems and personnel). Most parks are also not manned by state security agents or private security.

\section{Data and methodology}

This study is based on answers from a (cross-sectional) survey of tertiary students about safety in public transportation. The study, which is a part of a larger international project, attracted 270 valid responses on an internet-based 
questionnaire administration exercise, with about 95 percent of the respondents being Nigerian citizens. Collation of data on the experiences of commuters, especially undergraduate females using the diverse forms of PTS in Lagos metropolitan city, has provided us with first-hand information.

The online crowd-mapping technique employed targeted University of Lagos undergraduates who use public transport to and from campus. This represents a kind of digital campaign which encourages undergraduate public transport users, especially women and girls, to disclose their experiences within the broad context and themes provided by experts on public transport issues across the different continents and countries.

Our potential respondents were identified by pasting instructions at strategic locations on the campus as well as on a Google-created platform, inviting and stating that only those students who stay outside the campus and have reason to use PTS (bus, coaches, canoes, taxis, etc.) to commute to and from campus are eligible to participate in the study. Our recruited research assistants from the social sciences and statistics departments assisted us with the exercise. Unfortunately, because there are no statistics on public transport users among the population, we were unable to draw on a definitive list of public transit users but merely relied on willing participants. The quantitative data-generating technique used here has, as its merit, the advantage of measuring the reactions of our respondents on a wide range of questions, thus allowing the comparison and statistical aggregation of the data generated simultaneously across several countries of the world (see also Patton, 1990).

The process of data analysis started with sifting and editing the retrieved questionnaires for computer processing and analysis. The quantitative data generated from the survey were subsequently analyzed using descriptive statistical methods, and they were subjected to univariate level of analysis. At the univariate level, a simple percentage distribution pattern of the matrix type was used to disaggregate the necessary variables for the purpose of describing, summarizing and finding patterns in the data. This was done to answer the questions raised at the beginning of the study.

\section{The description of the sample}

The majority (94 percent) of the respondents were between the ages of 18 and 29 years, 5 percent were between 30 and 39 years, while 0.4 percent were between 40 and 49 years. In terms of gender, 42 percent of the respondents were male, 55.2 percent were female, 2 percent were transgender, while 0.7 percent of the respondents did not respond to the question. On sexual orientation of the respondents, the analysis reveals that 6 percent of the respondents admitted being homosexual, 82 percent are straight, 5 percent preferred not to disclose, while 8 percent of the respondents did not respond to the question. In terms of race/ethnic composition, 14 percent of the respondents were either black or African American, 0.4 percent were White/Caucasian, 0.7 percent were Hausa, 27 percent were Igbo, 37 percent, a majority, were Yoruba, 
0.4 percent came from the mixed race, while 21 percent were from another race/ethnic group category that was not specified. A description of the profile of the respondents is found in Table Al0.1.

\subsection{Results}

\section{Patterns of perceived safety by gender}

Women by far declared themselves to feel more often unsafe than men while in transit (Figure 10.2). In terms of perceived safety, a larger proportion of respondents who expressed feelings of lack of safety were females. For instance, 61 percent of women and 55 percent of men always feel unsafe using bus/keke napep (tricycle) or motorcycle stops at night. Similarly, 45 percent of female respondents and 39 percent of male respondents sometimes feel unsafe using bus/keke napep (tricycle) or motorcycle stops at night.

There are also gender differences in perception of safety while waiting at bus, keke napep (tricycle) or motorcycle stops during daytime and night-time (47 percent of males and 53 percent of females always feel unsafe, while for sometimes it is 40 percent of males and 62 percent of females). The sense of feeling unsafe becomes glaring and widens when it is dark for our respondents. While 33 percent of males always feel unsafe, a huge 67 percent of females always feel unsafe when it becomes dark. Whenever it is dark at the bust/keke/ tricycle stations, 31 percent and 69 percent, respectively, of males and females sometimes feel unsafe.

More often, female respondents declare feeling unsafe while walking to the station. In line to the gender differences of the general perception of safety found in the literature, we found that 50 percent of males and 58 percent of females expressed feelings that they always feel unsafe on the way to the station while 35 percent of males and 65 percent of females sometimes feel unsafe.

\section{Patterns of perceived safety by age}

Age is an important dimension as far as perception of safety is concerned. Older students tend to express more often concerns about their safety than the younger group (Figure 10.3). Considering feelings of safety by age, 5 percent and 8 percent of those younger than 30 and those above 30 years, respectively, expressed that they always feel unsafe using the use bus, keke napep (tricycle) or motorcycle. For those who sometimes feel unsafe, the figures are 20 percent and 15 percent respectively. While waiting at the bus, keke napep (tricycle) or motorcycle stop during the day, 9 percent of those younger than 30 and 13 percent of those older than 30 always feel unsafe, while 14 percent and 8 percent respectively sometimes feel unsafe. After dark, while the majority (33 percent) of those who were younger than 30 years said that they always feel unsafe, 23 percent of those older than 30 years always feel unsafe using public transportation after dark. Twenty-three percent of those younger than 30 years 


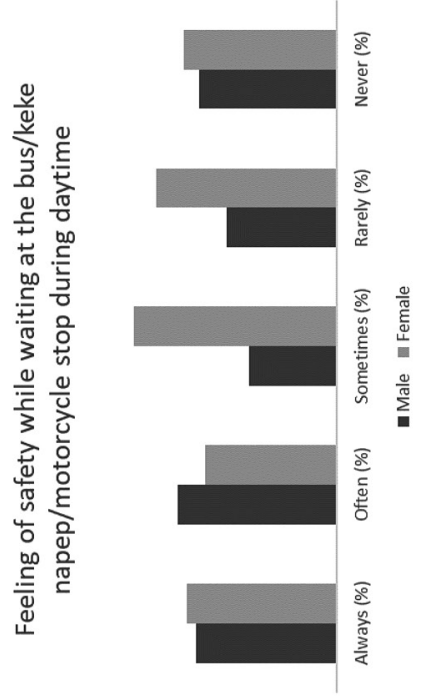

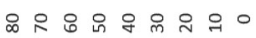

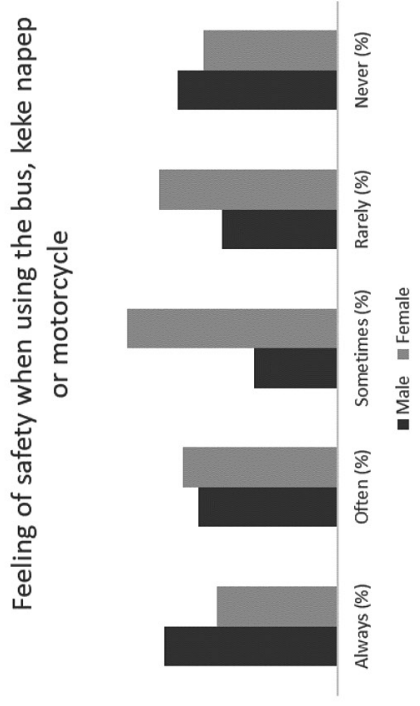

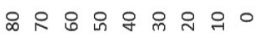

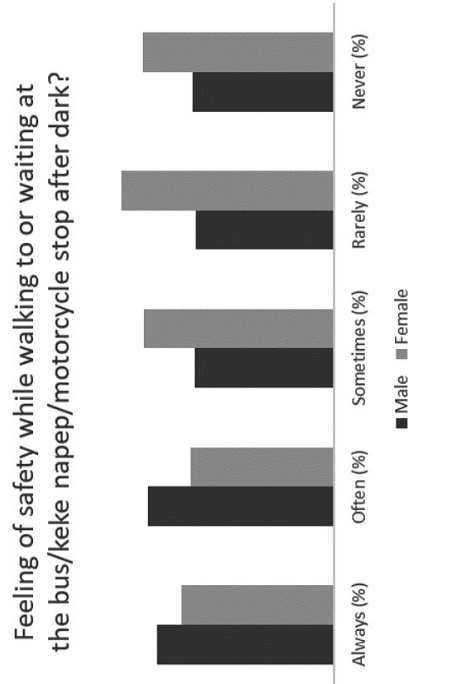

용용ㅇㅇㅇㅇㅇㅇㅇ

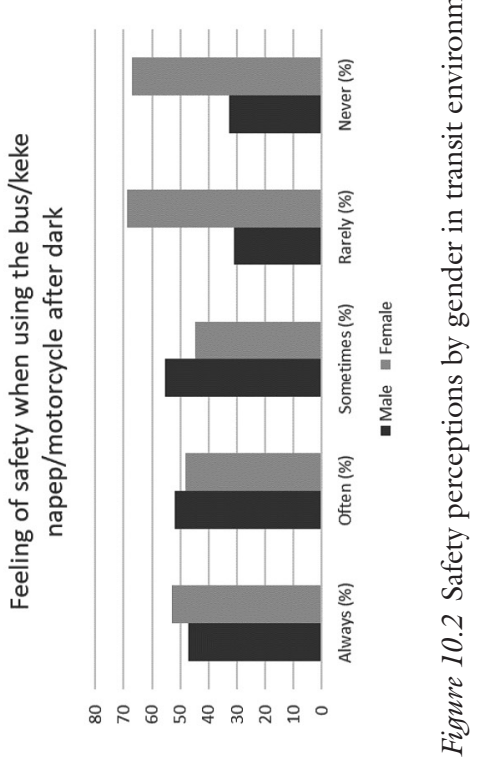




\section{Feeling of safety when using the bus/keke napep/motorcycle by age group}

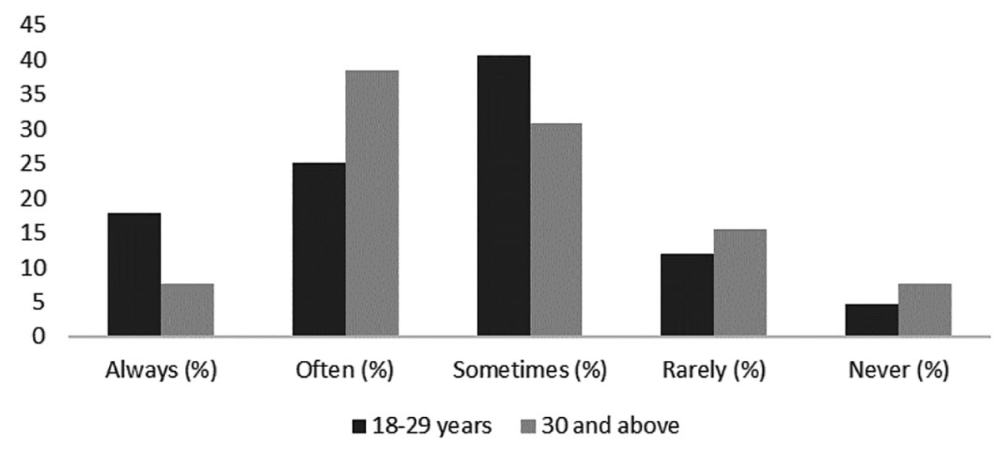

Figure 10.3 Safety perceptions by age groups in transit environments in Lagos, Nigeria.

and 15 percent of those older than 30 years sometimes feel unsafe using the bus, keke napep (tricycle) or motorcycle after dark. Thirty-seven percent of those below 30 years always feel unsafe while walking to the station, compared with 17 percent of those 30 years and above. Twenty-four percent of those younger than 30 years and 8 percent of those above 30 years sometimes feel unsafe while walking to the station, whether in the day or at night.

\section{Perception of safety problems while in transit}

Our respondents identified several problems most often encountered while using bus/keke napep (tricycle) and at the bus/keke napep (tricycle) or motorcycle stops (Table 10.1). These included drug use/abuse, presence of drunk people, manhandling and jewelry snatching. However, the most encountered problems were the use of obscene language ( 11 percent); pickpocketing (14 percent); poorly guarded/empty (6 percent); poorly illuminated area (9 percent); robbery; sexual harassment; vandalism/littering, and verbal/physical threats ( 13 percent). There are several reasons for entertaining fear while using public transport modes whether in the day or night. These range from antisocial behavior of others (17 percent), cost of tickets (10 percent). Other important fears are of sexual harassment on the bus/tricycle or motorcycle (4 percent), and fear of terrorist attack (4 percent). Interestingly, a large number (13 percent) said they had fear of traffic crashes (accidents). Other sundry reasons for non-use of public transport were for exercise and to save money, just staying on campus (immobility), stress and lack of comfort, lack of information about bus/tricycle or motorcycle schedules and the fact that service is always overcrowded. Seven percent of respondents declared that it is because it slows journey time, and 9 percent said there were unreliable or infrequent bus/tricycle or motorcycle services. 
Table 10.1 Respondents' concerns about using buses, tricycle or motorcycles in Lagos, Nigeria

\begin{tabular}{lcc}
\hline & Frequency & Percentage (\%) \\
\hline $\begin{array}{l}\text { Concern about antisocial behavior of others (such as; } \\
\quad \text { drinking, cursing, smelling badly, etc.) }\end{array}$ & 45 & 16.7 \\
Cost of tickets & 26 & 9.6 \\
Dirty environment during the walk to the bus/ & 2 & 0.7 \\
$\quad$ tricycle or motorcycle tickets & & \\
Do not understand how to buy bus/tricycle or & 1 & 0.4 \\
$\quad$ motorcycle tickets & 10 & 3.7 \\
Fear of sexual harassment on the bus/tricycle or & 11 & 4.1 \\
$\quad$ motorcycle & 36 & 13.3 \\
Fear of terrorist attack & & \\
Fear of traffic crashes & 12 & 4.4 \\
Fear of victimization getting to and waiting for the & 2 & 0.7 \\
$\quad$ bus/tricycle or motorcycle & 2 & 0.7 \\
For exercise and save, I often walk & 1 & 0.4 \\
I stay on campus & 1 & 0.4 \\
Its stressful & & \\
Lack of comfort & 3 & 1.1 \\
Lack of information about bus/tricycle or motorcycle & 2 & 0.7 \\
$\quad$ schedules & 24 & 8.9 \\
Many transfers & 18 & 6.8 \\
Overcrowded services & 1 & 0.4 \\
Slow journey times & & \\
The size of the tricycle is small & 278 & 8.5 \\
Unreliable or infrequent bus/tricycle or motorcycle & & 0.7 \\
$\quad$ service & & 17.8 \\
Other & & \\
No response & & \\
Total & & \\
\hline
\end{tabular}

In terms of sexual harassment, Table 10.2 shows the most common types of behavior that women encounter while in transit: unwanted sexual looks, using obscene/abusive language, calling you babe, honey sweetheart, groping, touching inappropriately but also indecent exposure and sexual comments.

\section{Perception of risk and precautionary measures}

When asked about why respondents do not use bus, keke napep (tricycle) or motorcycle transit more often to commute to campus, interestingly, 73 percent of the females declared it is due to fear of victimization while getting to or waiting at the bus stop or platform. In specific terms, 87.5 percent of the females declared that it is because of fear of sexual harassment in its various forms.

Public transport users in Nigeria do take some precautionary measures to guard themselves against both anticipated and unanticipated crimes, delinquent acts and other bad behaviors. Analysis of data reveals that 15 percent of the respondents described measures taken while using public buses/tricycle or 
Table 10.2 Problems of sexual harassment respondents encountered at the bus/tricycle/ motorcycle stops within the past 3 years in Lagos, Nigeria

\begin{tabular}{lrc}
\hline & Frequency & Percentage (\%) \\
\hline Asking one personal questions about sexual life. & 1 & 0.7 \\
Calling you babe, honey sweetheart & 33 & 12.2 \\
Giving me phone numbers & 1 & 0.4 \\
Groping, touching inappropriately & 32 & 11.9 \\
Indecent exposure & 16 & 5.9 \\
Making kissing sounds & 3 & 1.1 \\
Pulling or playing with your hair & 3 & 1.1 \\
Sexual comments & 14 & 5.2 \\
Showing pornographic images & 4 & 1.5 \\
Stalking & 29 & 10.7 \\
Unwanted sexual looks & 41 & 15.2 \\
Unwanted sexual teasing, remarks & 4 & 1.5 \\
Using obscene/abusive language & 34 & 12.6 \\
Whistling & 14 & 5.2 \\
Nothing & 2 & 0.7 \\
Others & 7 & 2.6 \\
No response & 32 & 11.6 \\
Total & 270 & 100.0 \\
\hline
\end{tabular}

motorcycle include always travelling with someone else, 0.7 percent said avoiding carrying purses and wallets, and 8 percent said avoiding particular bus/tricycle or motorcycle stops. Other measures include carrying some kind of weapons, dressing in a certain way, and another ( 5 percent) said being alert. Interestingly, some respondents said they do not take any cautionary measure except only to pray and believe in the grace of God. By and large, the most common cautionary measure was travelling only during daytime (27.0 percent of the respondents subscribe to this measure). There are also avoiding wearing jewelry, sitting close to the driver, waiting for transit at well-lit places, and waiting for transit only if other people are around. Table 10.3 illustrates the types of precautionary measures taken by respondents of the survey while in transit.

\subsection{Recommendations for safety improvement}

On what could be done to make traveling in public transport safe, our respondents responded enthusiastically. Several measures and strategies suggested included the use of cameras (CCTV) at bus stops and on the bus/tricycle or motorcycle (10.4 percent), 13 percent said it is the use of digital timetables at bus/tricycle or motorcycle stops, and 5 percent suggested having direct police hotlines-direct to police station/division within the precinct of the bus station-at bus/tricycle or motorcycle stops. Other suggestions were improved lighting at the bus/tricycle or motorcycle stops (12 percent), more police officers patrolling buses/tricycle or motorcycles (35 percent), and 4 percent said women-only buses/tricycles or motorcycles. 
Table 10.3 Precautionary measures taken by users of bus/tricycle/motorcycle stops

\begin{tabular}{|c|c|c|}
\hline & Frequency & Percentage (\%) \\
\hline Always travelling with someone else & 40 & 14.8 \\
\hline Avoiding carrying purses, wallets & 2 & 0.7 \\
\hline Avoiding particular bus/tricycle or motorcycle lines & 13 & 4.8 \\
\hline Avoiding particular bus/tricycle or motorcycle stops & 21 & 7.8 \\
\hline Being conscious of your environment & 1 & 0.4 \\
\hline Carrying some kind of weapon & 6 & 2.2 \\
\hline Dressing in a certain way & 14 & 5.2 \\
\hline \multicolumn{3}{|l|}{ Ensuring the degree of self-awareness is high, also } \\
\hline I try to be very much aware of my environment & 1 & 0.4 \\
\hline $\begin{array}{l}\text { I make sure all my valuables are in my bag and my } \\
\text { bag is always in front with me holding it tight } \\
\ldots \text { it is either I am with someone or I wait }\end{array}$ & & \\
\hline for bus if only males are there & 1 & 0.4 \\
\hline $\begin{array}{l}\text { No precaution per say because only prayer and } \\
\text { the grace of God can save }\end{array}$ & 3 & 1.1 \\
\hline Not wearing jewelry & 3 & 1.1 \\
\hline Sitting close to the driver & 8 & 3.0 \\
\hline Travelling only during daytime & 73 & 27.0 \\
\hline Waiting for transit at well-lit places & 23 & 8.5 \\
\hline Waiting for transit only if other people are around & 25 & 9.3 \\
\hline Others & 4 & 1.5 \\
\hline No response & 32 & 11.9 \\
\hline Total & 270 & 100.0 \\
\hline
\end{tabular}

\subsection{Discussion}

Commuters' safety is essential to public transport users in large towns, cities and metropolises. Our analysis reveals that safety, either while walking to a bus stop or waiting there, is a real concern among Nigerian public transport users, particularly female undergraduates, a majority of whom are represented in our sampled respondents. Fifty-five percent of males and 61 percent of females always feel unsafe while 39 percent of males and 45 percent of females 'sometimes' feel unsafe using bus/keke napep (tricycle) or motorcycle, taxis and buses. These figures, when pulled together, present a clear picture of the prevalence of fear and/or lack of a sense of safety when either moving to or waiting at public transport stops.

Although both men and women do feel unsafe when they use the PTS, they have starkly different experiences of public transport as they travel around the city (Lieberwirth, 2017). This accounts for the difference in the manner they commute from one place to another. We found in our study that greater numbers of University of Lagos female students (61 percent) do not feel safe at all and, as such, may have at one time or the other been victimized either walking to or waiting at the bus stops. This figure compares to 55 percent of male respondents, who said they always feel unsafe using PTS. Kalms and Korsmeyer $(2017 \mathrm{a}, \mathrm{b})$ explained that the observable difference in experiences 
(and perhaps safety feelings) between men and women who travel around cities can be attributed to the age-old trope of seeing women as the weaker sex and prone to vulnerability. Our findings confirm this difference in experience and the cautionary steps being taking while travelling. In a study by the University of California, these differences were found to be products of a long history of gender inequality, which reinforces rigid binary definitions of femininity and masculinity. It is argued that gender inequalities in transport use open myriad additional concerns (Lieberwirth, 2017).

Guilloux (2012) and Smith (2008) show that although both men and women do exhibit fear while using public transport, for women fear of crime is obviously higher. This explains the protective measures that women impose on themselves. A recent study showed that all women are more likely to adopt specific transport practices that range from vigilance to avoidance for fear of victimization (Guilloux, 2015). Kalms and Korsmeyer (2017a, 2017b) explained that women, and young and old people feel more at risk in areas near to public transport. These spaces include pedestrian subways and bridges, stations, access areas and bike paths. The feeling of fear by our respondents is understandable when we realized that in many cities in Nigeria, public transport facilities are poorly provided or simply not available. The presence of some delinquent behaviors being exhibited by both agberos (touts), drivers and co-commuters may have fueled the fear, especially by women.

In addition, of all the crimes and safety issues confronting our respondents particularly women and girls who utilize public transport for their daily activities, fear of sexual harassment, terrorist attack, and traffic crashes, remain the most common ones. While sexual harassment remains visible and takes several forms, the common forms include stalking, unwanted touching, obscene gestures, voyeurism, unwanted sexual comments or jokes, and unwanted offensive looks. Kalms and Korsmeyer $(2017 \mathrm{a}, \mathrm{b})$ are of the view that the fear of sexual harassment in urban areas predisposes girls and women to regularly modify their behavior to reduce their risk of harassment. In extreme cases, women and girls are less likely to undertake travel using the PTS than their male counterparts, make the most meticulous decisions about their clothing, find a male to go with and/or try to limit their movements to particular areas of the city (see also Kalms and Korsmeyer 2017a, 2017b). In this study, fewer than one-third (31 percent) of male respondents experienced sexual harassment, in contrast to 46 percent of the female respondents who experienced the same crime. Of course, this is in tandem with the findings of other studies (see for example, TTC et al., 1989, cited in Smith, 2008).

There are several crimes and socially deviant behaviors identified by our respondents as constraints to their use of public transportation to move about for their routine activities. Drug use/sales remains a significant one. In addition there is the presence of drunk people, the use of obscene language, and panhandling. Other constraining behaviors are pickpocketing, being poorly guarded, poor illumination, robbery, sexual harassment, vandalism/littering, verbal/physical threats, and violent crime (aggravated assault and murder). 
These findings are in line with the findings of Borhan et al. (2019) and Otu (2017). For these authors, the PTS is fraught with additional challenges, restraining the preference of it. These challenges include unavailability or inaccessibility to some residents, its erratic schedule and long travel time due to frequent stops and pick-ups, robbery insults and assaults. Smith and Cornish (2006) identified crimes against users, crimes against employees of transit systems, line-of-route related offenses, graffiti and vandalism as some of the challenges faced by public transport users. These and our findings constitute additional sources of fear and feelings of lack of safety by our undergraduate public transport users.

The main reason(s) for entertaining fear whether in the day or night among our respondents is antisocial behavior of others. When we sum up the number of people who said it is because of fear of terrorist attack, and being victimized, then the picture of the correlation between the use of public transport and feelings of safety becomes compelling. Interestingly, a few of our respondents (13 percent) said it is the fear of traffic crashes (accidents), and cost of tickets (10 percent). Social Exclusion Unit (2003) found that, when the cost of a ticket is high, it became a constraint among residents of England.

The fear of crime and feelings of being unsafe when using public transport have made users devise different cautionary measures for survival and conviviality (for more on behavior modifications, see Kalms and Korsmeyer, 2017a, $2017 \mathrm{~b}$ ). Analysis of data reveals that 15 percent of the respondents always avoid travelling alone, while others avoid particular public transport lines and stops. In extreme case, some public transport users carry some kind of weapon, or defensive objects; dress in a certain way, especially among females, including not wearing jewelry; being overtly conscious and alert; and making sure all valuables are in a bag which is held tight. Prayer and submission to the "will and grace of God' is also favored by Nigerian undergraduate females using public transportation. The majority, however, favored travelling during daytime. At least 27 percent of our respondents take this path.

\subsection{Conclusion and policy implications}

This chapter set out to report transit safety conditions experienced by college students in Lagos, Nigeria, using answers from a small sample survey of tertiary students. Findings from this study indicate that students who attend school from town, and who use public transportation, are susceptible to all forms of unwanted sexual behaviors and miscreant activities. This challenges us to answer the question as to what could be done to improve safety on PTS and reduce fear among students That is, what are the policy implications of dour findings?

First, the conscious design of facilities, internal design of vehicles, and the environments (routes) that public transport traverses should be improved. For example, bus stops/stations should be designed in a manner that they have separate waiting rooms for both males and females; coaches and buses should have a section designated for females; while designated routes should be reserved for 


\section{Smart E. Otu and Augustine Agugua}

some coaches/buses, as is currently done by the Lagos State Transport Authority. This suggestion aligns with Crime Prevention Through Environmental Design (CPTED) which is increasingly being used in PTS, such as train stations (see Public Transport Safety, n.d).

As transport networks are part of the urban environment (Public Transport Safety, n.d), the CPTED interventions we recommend here must envision and include a Safe Women project, which should involve re-designing public spaces to help prevent sexual aggression. CPTED is concerned with altering the physical environment to impact offender decision-making. This should include improvements to pedestrian walkways along the main access routes to the transport system, ensuring they are well lit and equipped with safety equipment, as well as improving lighting in the city center and residential areas (see also UN Women, n.d.). Ceccato, Uittenbogaard, and Bamzar (2013) explained that lighting seems to play a role in variations in the crime rate. A study in the UK found that poorly lit places increased fear of crime (Crime Concern, 2004).

Table A10.1 The profile of respondents

\begin{tabular}{|c|c|c|}
\hline Variables & Frequency & Percentage (\%) \\
\hline \multicolumn{3}{|l|}{ Age } \\
\hline $18-29$ & 255 & 94.4 \\
\hline $30-39$ & 14 & 5.2 \\
\hline $40-49$ & 1 & 0.4 \\
\hline Total & 270 & 100.0 \\
\hline \multicolumn{3}{|l|}{ Gender } \\
\hline Male & 115 & 42.6 \\
\hline Female & 149 & 55.2 \\
\hline Transgender & 4 & 1.5 \\
\hline Prefer not to say & 2 & 0.7 \\
\hline Total & 270 & 100.0 \\
\hline \multicolumn{3}{|l|}{ Sex status (LGBTQI) } \\
\hline Yes & 16 & 5.9 \\
\hline No & 220 & 81.5 \\
\hline Prefer not to say & 13 & 4.8 \\
\hline No response & 21 & 7.8 \\
\hline Total & 270 & 100.0 \\
\hline \multicolumn{3}{|l|}{ Race/ethnicity } \\
\hline Black/African American & 37 & 13.7 \\
\hline White/Caucasian & 1 & 0.4 \\
\hline Hausa & 2 & 0.7 \\
\hline Igbo & 74 & 27.4 \\
\hline Yoruba & 99 & 36.7 \\
\hline Mixed Race & 1 & 0.4 \\
\hline Others & 56 & 20.7 \\
\hline Total & 270 & 100.0 \\
\hline
\end{tabular}


Second, mechanisms should be put in place that can facilitate easy and prompt reporting of incidents of crime and antisocial behavior to the appropriate authorities. To achieve this requires sensitization of the people mostly likely to use public transport.

Third, security should be enhanced through effective use of motorized and foot patrols by special units of the police around major bus/train/ferry/canoe stops in and around Lagos metropolis. Engage public transport providers to do more to establish greater security for their customers through the provision of CCTV cameras, alarm buttons and visible state and private security guards on public transport routes and spaces. Police patrols, both at the buses/tricycle and around the platforms, is a strong preventive measure. Visible police patrols has been highlighted as the densities of passengers (overcrowding), e.g., in buses, carriages, and stations, are commonly a fertile territory for sexual harassment and other types sexual abuse and harassment. Sherman and Eck (2002), and Weisburd and Eck (2004) share in this view when they suggested that policing geared towards reducing crime is specifically beneficial if it is targeted at highcrime locations.

Finally, since our findings support the extant literature that females, and old and low income people - a majority of whom are public transport users-are more likely to be victimized, express fear, and are less likely to report to the appropriate authority when victimized, a modern PTS that is gender- age- and class-sensitive, safe and accessible should constitute part of the overall revolution of public transport policy.

\section{References}

Bidstrup, S. (1999). So you're planning a trip to Africa. A page of advice travellers to Africa. www.pe.net/ bidstrup/advice.htm (accessed 16 February 2020).

Borhan, M., Ibrahim, A. N. H., Syamsunur, D., \& Rahmat, R. A. (2019). Why public bus is a less attractive mode of transport: a case study of Putrajaya, Malaysia. Periodica Polytechnica Transportation Engineering, 47, 82-90.

Brantingham, P. L., \& Brantingham, P. J. (1993). Environment, routine and situation. Toward a pattern theory of crime. In R. Clarke and M. Felson (Eds), Routine Activity and Rational Choice: Advances in Criminological Theory, New Jersey: Transactional Publishers.

Brantingham, P. L., \& Brantingham, P. J. (1995). Criminality of place: crime generations and crime attractors. European Journal on Criminal Policy and Research, 3, 5-6.

Bottoms, A. E., \& Wiles, P. (1997). Environmental criminology. In M. Maguire, R. Moran, \& R. Reiner (Eds), The Oxford Handbook of Criminology (pp. 620-656).

Cawley, M. (2014). Aumento de secuestro 'express' es señal de la evolución criminal de Colombia. http://es.insightcrime.org/noticias-del-dia/aumento-desecuestro-expressigno-de-la-evolucion-criminal-de-colombia (accessed 11 September 2018).

Ceccato, V., Uittenbogaard, A., \& Bamzar, R. (2013). Security in Stockholm's underground stations: the importance of environmental attributes and context. Security Journal, 26, 33-59.

Ceccato, V., \& Paz, Y. (2017). Crime in São Paulo's metro system: sexual crimes against women. Crime Prevention and Community Safety, 19, 211-226.

Ceccato, V., \& Loukaitou-Sideris, A. (2020). Transit Crime and Sexual Violence in Cities: International Evidence and Prevention. London: Routledge. 


\section{Smart E. Otu and Augustine Agugua}

Chen, J., \& Gursoy, D. (2001). An investigation of tourists' destination loyalty and preferences. International Journal of Contemporary Hospitality Management, 13, $79-85$.

Clarke, R., \& Eck, J. (2003). Become of Problem-solving Crime Analyst in 55 SMALL STEPS. Devon, UK: William Publishing.

Cohen, L., \& Felson, M. (1979). Social change and crime rate trends: a routine activity approach. American Sociological Review, 44, 588-608.

Cornish, D., \& Clarke, R. (1986). The Reasoning Criminal. New York: Springer-Verlag.

Control Risks (2016). Risk Map. https://riskmap.controlrisks.com/ (accessed 28 August 2018).

Cozens, P., Neale, R., Whitaker, J., \& Hillier, D. (2003). Managing crime and the fear of crime at railway stations-A case study in South Wales (UK). International Journal of Transport Management, 1, 121-132.

Crime Concern (2004). People's Conceptions of Personal Security and their Concerns About Crime on Public Transport: Research Findings. London: Department for Transport.

Friman, M. (2004). The structure of affective reactions to critical incidents. Journal of Economic Psychology, 25, 331-353.

Friman, M., Edvardsson, E., \& Gärling, T. (1998). Perceived quality of public transport service: inference from complaints and negative critical incidents. Journal of Public Transportation, 2, 69-91.

Gekoski, A. Gray, J., Horvath, M., Edwards, S., Emirali, A., \& Adler, J. R. (2015). 'What Works' in Reducing Sexual Harassment and Sexual Offences on Public Transport Nationally and Internationally: a Rapid Evidence Assessment. Project Report. Middlesex University; British Transport Police; Department for Transport, London.

Guilloux, M. (2012). La prévention des violences faites aux femmes dans les transports collectifs français. Montréal: CIPC.

Guilloux, M. (2015). Les violences faites aux femmes dans les transports collectifs terrestres: Synthèse de l'étude exploratoire. Paris: Ministère de l'Écologie, du Développement durable et de l'Énergie.

Harris, O. (1971). A Methodology for Developing Security Design Criteria for Subways. Washington, DC. Urban Mass Transit Administration, Report No. UMTA-URT-5 (70)-71-4 (accessed 10 November 2018).

International Center for the Prevention of Crime (n.d.) www.crime-prevention-intl.org (accessed 10 November 2018).

Iveson, D. (2018). Edmonton to host world leaders on safe public spaces. https:// myemail.constantcontact.com/News-Release-Edmonton-to-host-world-leaders-onsafe-public-spaces.html?soid=1127191170163\&aid=nzHCBnlJIf0 $($ accessed 10 November 2018).

Kalms, N., \& Korsmeyer, H. (2017a). Gender makes a world of difference for safety on public transport. www.smh.com.au/lifestyle/gender-makes-a-world-of-difference-forsafety-on-public-transport-20170718-gxd8ee.html (accessed 1 January 2019).

Kalms, N., \& Korsmeyer, H. (2017b). Preventing sexual harassment in Australian public transport spaces through gender-sensitive co-design with women and girls. Uncovering how the safety of women and girls is challenged in public transport spaces. www. monash.edu/mada/research/labs/xyx-lab-monash-space-gender-communication-lab (accessed 1 January 2019).

Lagos State Government (2002). Lagos State Development Indicators Report. lhttps:// lagosstate.gov.ng/ (accessed 10 July 2018).

Le Parisien (2011). Frauder dans le bus deviant la règle. Le Parisien.fr. www.leparisien. $\mathrm{fr} / \mathrm{une} /$ frauder-dans-le-bus-devient-la-regle-17-01-2011-1230490.php (accessed 20 December 2018). 
Lieberwirth, R. (2017). Gender makes a world of difference for safety on public transport. https://theconversation.com/gender-makes-a-world-of-difference-for-safety-onpublic-transport-80313 (accessed 20 December 2018).

Loukaitou-Sideris, A., Liggett, R., \& Iseki, H. (2001). The geography of transit crime: documentation and evaluation of crime incidence on and around Green Line Stations in Los Angeles. Journal of Planning Education and Research, 22, $135-151$.

Morgan, R., \& Smith, M. J. (2006). Crimes against passengers: theft, robbery, assault and indecent assault. In D. B. C. M. J. Smith (Ed.), Secure and Tranquil Travel: Preventing Crime and Disorder on Public Transport (pp. 77-102). London: Jill Dando Institute of Crime Science.

National Bureau of Statistics (2017). Demographic Statistics Bulletin. Nigeria. Available at https://nigerianstat.gov.ng/download/775 (accessed 25 April 2020).

Newton, A. D. (2004). Crime on public transport: 'static and 'non-static' (moving) crime events. Western Criminology Review, 5, 25-42.

Nurdden, A., Rahmat, R. A. O. K., \& Ismail, A. (2007). Effect of transportation policies on model shift from private car to public transport in Malaysia. Journal of Applied Sciences, 7, 1014-1018.

Okpara, E. E. (1988). The role of touts in passenger transport in Nigeria. The Journal of Modern African Studies, 26, 327-335.

Opeifa, K. (2012). How do we harness electricity to transform social infrastructure? 7 th Lagos Economic Summit on Powering the Lagos Economic Real Opportunities, Endless Opportunities.

Otu, S. E. (2003). Armed robbery in the south eastern states of contemporary Nigeria: a criminological analysis. Unpublished Doctoral thesis (D. Litt. Phil.) Department of Criminology, University of South Africa (Unisa), Pretoria.

Otu, S. E. (2017). Patterns and modus operandi of crime and disorderly conduct on the public transport system in Abakaliki, Nigeria: a descriptive analysis. In E. C. Viano (Ed.) Cyber Crime, Organised Crime, and Societal Responses, Internal Approach (pp. 341-365). Switzerland: Springer International Publishing.

Patton, M. Q. (1990). Qualitative Evaluation and Research Methods. Newbury Park, CA: Sage Publications.

Public Transport Safety (n.d). Preventing crime on urban public transport. www.jstor. org/stable/1147664? seq=1.

Salau, T. (2015). Public transportation in metropolitan Lagos, Nigeria: analysis of public transport users' socioeconomic characteristics. Urban, Planning and Transport Research, 3, 132-139.

Schäfer, I. (2015). Ciudades latinoamericanas estudian cómo predecir el crimen. El País.com. http://internacional.elpais.com/internacional/2015/07/30/actualidad/1438211440_ 366876.html (accessed 10 July 2018).

Sherman, L., \& Eck, J. (2002). Police for crime prevention. In: Sherman, L., Farrington, D., Welsh, B. and Layton MacKenzie, D. (Eds), Evidence-Based Crime Prevention. London: Routledge.

Smith, M. J., Belenko, S., Staehs, G., Arriola, R., Shea, R., Truitt, L., \& Harsch, D. (1986). Transit Crime Study, Vol. 1, Summary of Findings and Policy Recommendations. New York: New York City Criminal Justice Agency..

Smith, M. J. (2008). Addressing the security needs of women passengers on public transport. Security Journal, 21, 117-133.

Smith, M. J., \& Cornish, D. B. (Eds) (2006). Secure and Tranquil Travel: Preventing Crime and Disorder on Public Transport. London, UK: UCL, Jill Dando Institute of Crime Science. 


\section{Smart E. Otu and Augustine Agugua}

Social Exclusion Unit. (2003). Making the connections: Final report on transport and social exclusion.www.ilo.org/wcmsp5/groups/public/@ed_emp/@emp_policy/@invest/ documents/publication/wcms_asist_8210.pdf (accessed 2 January 2019).

Toronto Travel Commission (TTC), Metro Action Committee on Public Violence against Women and Children (METRAC), and the Metro Toronto Police Force (MTPF) (1989). Moving Forward: Making Transit Safer for Women. Toronto, Canada: TTC, METRAC, and MTPF.

UN Women. (n.d.). Encouragez les organismes de transports publics et privés à intégrer des perspectives sexo spécifiques dans leurs opérations quotidiennes. Retrieved from www.endvawnow.org/fr/articles/288-encouragez-les-organismesde-transports-publics-etprives-a-integrer-des-perspectivessexospecifiques-dans-leurs-operations-quotidiennes. html (accessed and interpreted by expert 2 February 2019).

UITP (2014). Rapport Sûreté 2013. Paris: UTP.

Weisburd, D., \& Eck, J. (2004). What can police do to reduce crime, disorder and fear? The Annals of the American Academy of Political and Social Science, 593, 42-65. 